\title{
PENGETAHUAN KESEHATAN REPRODUKSI REMAJA DALAM MENCEGAH PENYIMPANGAN SEKSUAL
}

\author{
Husnin Nahry Yarza, Maesaroh, Eka Kartikawati \\ Pendidikan Biologi FKIP Universitas Muhammadiyah Prof. Dr.Hamka \\ Email corespondensi: husnin.rahry@uhamka.ac.id
}

\begin{abstract}
This community service aims to direct the community to a healthy lifestyle related to reproductive health. The subjects of service are high school adolescents who are vulnerable to the negative influence of social and environmental media. Reproductive health is very important for both men and women. Reproductive health is defined as a whole physical, mental and social well-being not free from disease or disability in all matters relating to the reproductive system, its functions and processes. This service at the high school level is very necessary to be carried out by using location search methods, approaches to the school and providing workshops to students. With this service can provide students with knowledge and insight into reproductive health and sexual deviations that they must avoid. Adolescent reproductive health is an inseparable part of mental health, mental health and social health. Teenagers must understand and know their sexual reproductive health so as not to produce sexual deviations that will harm themselves and their families.
\end{abstract}

Keywords: healthy reproduction, sexual aberation, teenager, prevention

\section{Abstrak}

Pengabdian masyarakat ini bertujuan untuk mengarahkan masyarakat pada pola hidup sehat terkait dengan kesehatan reproduksi. Subjek pengabdian yaitu remaja tingkat SMA yang rentan terhadap pengaruh negatif media sosial dan lingkungan. Kesehatan reproduksi hal yang sangat penting untuk pria maupun wanita. Kesehatan reproduksi didefenisikan sebagai suatu kesejahteraan fisik, mental dan sosial secara utuh tidak bebas dari penyakit atau kecacatan dalam semua hal yang berkaitan dengan sistem reproduksi, fungsi dan prosesnya. Pengabdian di tingkat sekolah menengah atas ini sangat perlu untuk dilaksanakan dengan menggunakan metode pencarian lokasi, pendekatan kepada pihak sekolah dan pemberian workshop kepada peserta didik.. Dengan adanya pengabdian ini dapat memberikan pengetahuan dan wawasan siswa dalam kesehatan reproduksi dan penyimpangan seksual yang harus mereka hindari. Kesehatan reproduksi remaja merupakan bagian yang tidak dapat dipisahkan yakni kesehatan psikis, mental dan kesehatan social. Remaja harus memahami dan mengetahui kesehatan reproduksi seksual mereka agar tidak menghasilkan penyimpangan-penyimpangan seksual yang akan merugikan diri sendiri dan keluarga.

Kata kunci: kesehatan reproduksi, penyimpangan seksual, remaja, pencegahan

\section{PENDAHULUAN}

Kesehatan reproduksi merupakan hal yang sangat penting untuk pria maupun wanita. Kesehatan reproduksi didefinisikan sebagai suatu kesejahteraan fisik, mental dan sosial secara utuh tidak semata-mata bebas dari penyakit atau kecacatan dalam semua hal yang berkaitan dengan sistem reproduksi, fungsi dan prosesnya (Aisyaroh, Noveri). Sedangkan remaja atau adolescene adalah yang berarti tumbuh ke arah kematangan. Kematangan yang dimaksud disini adalah kematangan secara fisik, sosial dan psikologis. Masa remaja merupakan 
masa transisi yang ditandai oleh adanya perubahan fisik, emosi dan psikis.

$$
\text { Perkembangan masa remaja }
$$
merupakan menuju kedewasaan. Proses ini merupakan proses untuk mencapai kemasakan dalam berbagai aspekfisik, psikis dan emosi. Dari sudut pandang kesehatan, tindakan menyimpang yang akan menghawatirkan yakni penyimpangan seksual yang berupa seks bebas, penyebaran penyakit kelamin, kehamilan di luar nikah atau kehamilan tidak dikehendaki di kalangan remaja (Pertiwi, Ratna Kartika).

Penyimpangan seksual adalah aktivitas seksual yang ditempuh seseorang untuk mendapatkan kenikmatan seksual dengan tidak sewajarnya. Biasanya, cara yang digunakan oleh orang tersebut adalah menggunakan obyek seks yang tidak wajar. Penyebab terjadinya kelainan ini bersifat psikologis atau kejiwaan, seperti pengalaman sewaktu kecil, dari lingkungan pergaulan, dan faktor genetik. Pada umumnya orang-orang yang mengalami penyimpangan seksual menyembunyikan perilaku mereka dan tidak mau mengakuinya. Mereka menolak mengakui perilaku seksual yang menyimpang dari norma sosial, moral dan agama karena kekhawatiran akan munculnya penolakan dan diskriminasi dari lingkungan. Masalah seksual sangat sensitif, baik secara moral maupun normative, akan berpengaruh terhadap nama baik seseorang (Abidin, Anwar Achmad; 2008).

Permasalahan yakni masih kurangnya pengetahuan remaja atau peserta didik dalam mengetahui tentang kesehatan reproduksinya, kurang paparan tentang menjaga kesehatan reproduksinya dan berbagai penyimpangan yang terkadang meraka lebih banyak ketahui dari media sosial. Maka diperlukannlah kegiatan pengabdian ini dilaksanakan. Karena dengan adanya pengabdian ini diharapkan dapat mengkomunikasikan seputar kesehatan reproduksi dan mengurangi mencegah adanya prilaku penyimpangan seksual.

\section{METODE PELAKSANAAN}

Metode yang digunakan pada pelaksanaan pengabdian masyarakat ini adalah:

a. Mencari lokasi yang membutuhkan, Kegiatan diawali dengan melakukan pencarian sekolah melalui penelitian pendahuluan untuk mengidentifikasi kebutuhan masyarakat yang ada di daerah yang akan direncanakan. Anggota pelaksana tinggal tidak jauh dari daerah yang akan dilaksanakan pengabdian jadi kondisi daerah sudah cukup diketahui serta kebutuhan daerah setempat sudah dipahami dengan baik.

b. Pendekatan pada pihak sekolah

Tahapan selanjutnya adalah melakukan pendekatan ketua pelaksana dengan pihak sekolah setempat. Minta pernyataan perjanjian kerjasama terkait diadakannya kegiatan pengabdian masyarakat di daerah tersebut.

c. Pihak Sekolah mengumpulkan siswa/siswi yang dirasa perlu 
Setelah proposal di ACC maka diadakan komunikasi lebih lanjut dengan pihak sekolah guna sosialisasi kepada pihak sekolah khususnya siswa untuk kegiatan workshop kesehatan reproduksi ini yang telah dihadiri oleh 45 orang siswa.

d. Pemberian workshop kepada peserta didik

Setelah diadakan kesepakatan dengan pihak sekolah, selanjutnya kegiatan awal diadakan. Kegiatan awal merupakan kegiatan workshop kegiatan yang akan dilaksanakan oleh ketua tim dan anggota. Selanjutnya peserta dibimbing untuk dapat menyampaikan bagi yang memiliki keluhan maupun kerisauan terkait dengan kesehatan reproduksi maupun tentang penyimpangan seksual. Dan terakhir diadakan games untuk mengetahui pengetahuan yang sudah didapatkan selama kegiatan berlangsung.

\section{HASIL DAN PEMBAHASAN}

Dari hasil pengabdian masyarakat ini didapatkan bahwa masih banyak siswa SMA Negeri 1 Sukakarya yang masih bingung dan malu dalam membicarakan kesehatan reproduksi. Dikarenakan mereka merasakan bahwa topik yang dibicarakan ini masih tabu dan takut untuk mempertanyakannya. Mereka lebih banyak menggunakan internet, bertanya pada teman dan sosial media untuk mengetahui seputar kesehatan reproduksi.

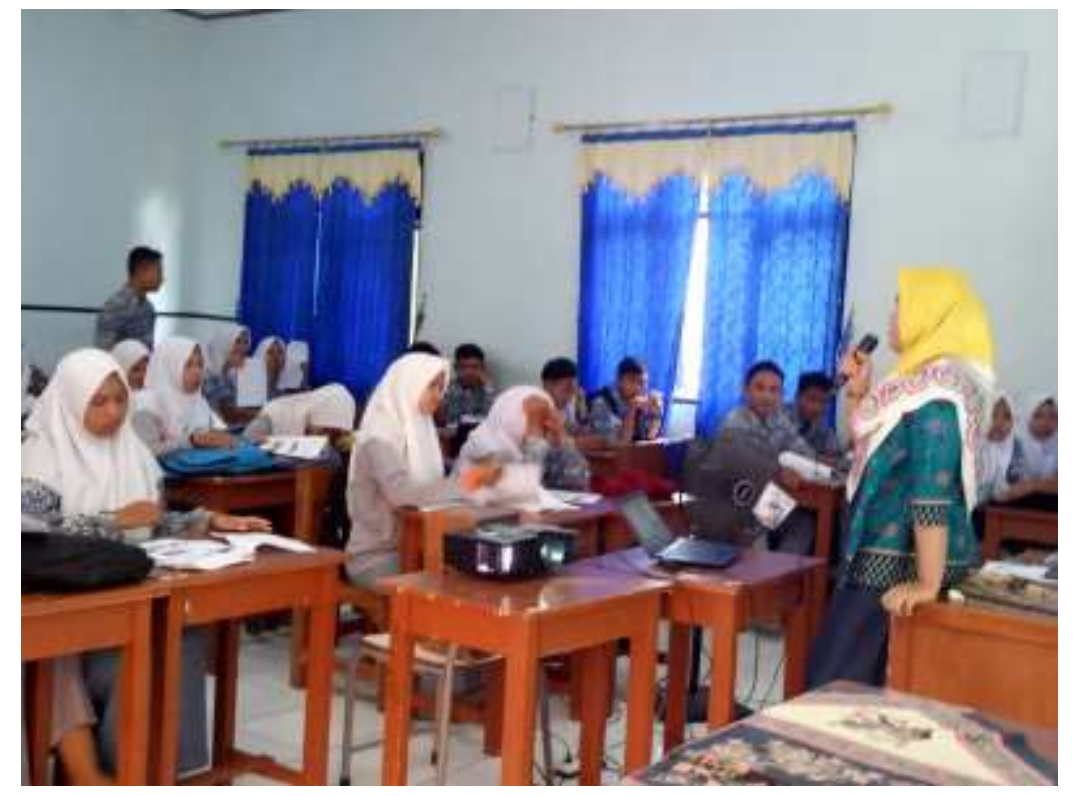

\section{Gambar 1. Narasumber sedang menyampaikan materi}

kesehatan reproduksi remaja.

Pada pengabdian ini siswa untuk melihat penguasan dan diberikan materi dan diberikan angket pemahaman materi mereka. Dari 
pengisian angket kegiatan ini didapatkan informasi bahwa sebanyak $93.3 \%$ siswa sudah mengetahui tentang apa itu istilah kesehatan reproduksi, sedangkan $6,7 \%$ siswa belum pernah mendengar istilah kesehatan reproduksi. Ini menunjukkan bahwa mereka sudah mengetahui apa itu kesehatan reproduksi. Menurut Nasution (2012) pengetahuan remaja tentang kesehatan reproduksi dan cara-cara melindungi dirinya terhadap resiko kesehatan masih sangat rendah dan menjadi perhatian kita semua. Pengetahuan dan pemahaman mereka seputar kesehatan reproduksi masih rendah dan hal ini membuat remaja masih sangat rentan dan beresiko terhadap kesehatan. Orang tua merupakan sumber informasi terbaik yang dapat mempengaruhi pengetahuan remaja (Ernawati, Hery., 2018).

Kesehatan reproduksi merupakan suatu keadaan, kondisi dimana remaja sehat secara sosial, fisik, mental, yang berkaitan dengan sistem reproduksi, fungsi reproduksi dan peran reproduksi yang dimiliki oleh remaja. Masa remaja yakni masa antara anak-anak menuju masa dewasa (Miswanto, 2014). Remaja haruslah memiliki sikap serta tingkah laku yang bertanggung jawab mengenai proses reproduksi agar memiliki informasi yang benar. Kesehatan reproduksi menurut ahli adalah suatu kondisi ketika proses reproduksi tercapai dalam situasi kesehatan fisik,mental dan sosial yang sempurna (Darwin, Muhadjir, 1996). Kesehatan reproduksi juga dipengaruhi oleh gizi, kesehatan psikologis, ekonomi dan ketidak- setaraan gender yang menyulitkan remaja putri menghindari hubungan seks yang dipaksakan atau seks komersial (UNFPA, 2016).

Dalam melakukakan hubungan seks secara bebas ada namanya penyakit PMS/ Penyakit Menular Seksual. Penyakit Menular Seksual merupakan penyakit yang ditularkan melalui hubungan seksual. Penyakit Menular Seksual ini lebih beresiko bila melakukan hubungan seksual dengan berganti-ganti pasangan baik melalui vagina, anal maupun oral.. banyak jenisnya penyakit menular seksual yaitu gonore, sifilis, herpes, dan HIV (Human Immunideficiency Virus). Penyakit lainnya yakni LGBT (Lesbian, Guy, Biseksual dan Transgender).

Banyak cara untuk mencegah penyimpangan seksual diantara nya yaitu jauhi lingkungan yang mengajak melakukan penyimpangan seksual, bersikap tegas, katakan tidak pada perbuatan maksiat, pengendalian diri, jangan minum alkohol dan obat terlarang, membentengi diri dengan pengetahuan agama.

\section{PENUTUP}

Kesimpulan yang didapatkan dari kegiatan pengabdian masyarakat ini adalah: Siswa lebih mengetahui apakah itu kesehatan reproduksi mereka, dan cara mereka untuk menjaga diri; Siswa juga menjadi lebih berani dalam menanyakan informasi seputar kesehatan seksual mereka; Masih banyak siswa yang belum paham dan mengangap membicarakan kesehatan 
reproduksi sebagai suatu hal yang ditakuti; Diperlukan pendidikan seks sejak usia dini untuk mencegah dan menjauhi dari prilaku seks yang tidak diinginkan dan menghindari penyimpangan seksual. Dan diperlukan pengbdian masyarakat selanjutnya untuk penyampaian materi kegiatan pada SMA-SMA di berbagai daerah.

\section{DAFTAR PUSTAKA}

Abidin, Anwar Ahmad. 2008. Prilaku Penyimpangan Seksual dan Upaya Pencegahannya di Kabupaten Jombang. Prosiding Seminar Nasional dan Temu ILMIAH Jaringan Peneliti IAI Darussalam Blokagung Banyuwangi. ISBN: 978-602-50015-0-5

Aisyaroh, Noveri. Kesehatan Reproduksi Remaja. FIK Unissula.

Darwin, Muhadjir. 1996.Kesehatan Reproduksi: Ruang Lingkup dan Kompleksitas Masalah. Populasi. Vol. 7 No. 2.

Ernawati, hery. 2018. Pengetahuan Kesehatan Reproduksi Remaja di Daerah Pedesaan. Indonesian
Journal for Health Sciences. Vol. 02 No. 01. P. 58-64.

Maesaroh, . 2017. Laporan Penelitian Perspektif remaja tentang kesehatan reproduksi sebagai upaya pencegahan dini penyimpangan seksual di Bekasi. Jakarta: UHAMKA.

Miswanto, 2014. Pentingnya Pendidikan Kesehatan Reproduksi dan Seksualitas Remaja. Jurnal Studi Pemuda. Vol 3 no. 2. P. 111-121.

Nasution, Sri Lilestina. 2012. Pengaruh Pengetahuan Tentang Kesehatan Reproduksi Remaja Terhadap Perilaku Seksual Pranikah Remaja di Indonesia. Widyariset. Vol 15. No. 1 p.75-84.

Pertiwi,Kartika Ratna. Kesehatan Reproduksi Remaja dan Permasalahannya. FMIPA UNY.

Tim LPPM UHAMKA. 2018. Buku Panduan Pengabdian Mayarakat UHAMKA. Jakarta: UHAMKA.

UNFPA. 2016. Outlook. Kesehatan Reproduksi Remaja: Membangun Perubahan yang Bermakna. Volume 16. 